$\begin{array}{ccc}\text { Original Article } & \text { Journal of ocial Research and Behavioral Sciences } \\ \text { Received/Accepted } & \text { Dates } & \text { Sosyal Araştırmalar ve Davranış Bilimleri Dergisi } \\ \text { DOI } & \begin{array}{l}\text { 25.10.2021/29.11.2021 } \\ \text { 10.52096/jsrbs.6.1.7.13.36 }\end{array} & \text { ISSN:2149-178X }\end{array}$

Volume: 7 Issue: 13 Year: 2021

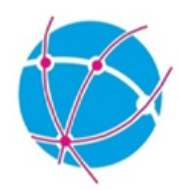

\title{
Resimde Duygu ve Gerilimin Çekiciliği Francis Bacon (1909-1992)
}

Doç. Dr. Ayfer UZ

Trakya Üniversitesi

Eğitim Fakültesi

Güzel San. Ĕg. Bölümü

Resim-İş Eğitimi ABD.

ayfer_uz@hotmail.com

ayferuz@trakya.edu.tr

\section{Özet}

Francis Bacon 1909'da İngiliz bir ailenin çocuğu olarak Dublin'de dünyaya gelir. Sıra dışı kimliği ve duyarlılığı ile dikkat çeken sanatçı edebi olanı reddeder ve resmini doğrudan expresyonist olarak görür. Yaşadığı dönem ve onun üzerinde bıraktığı etki resimlerine yansır ve korku veren imgelerden oluşan yapıtlar ortaya çıkar. Resimlerindeki figürler çarpılmış, güçlü bir devinim içinde hapsolmuş, bir girdaba ya da firtınaya kapılmış gibilerdir. Figürün duygusal gerilimine ortak olan izleyen de eserin karşısında yoğun duygular yaşar.

Nitel araştırma yöntemiyle yapılan bu çalışmanın amacı; akademik bir sanat eğitimi almamış olmasına karşın böylesine güçlü duygu etkisini sanatıyla seyirciye geçirmeyi başaran ve sanat tarihinde hak ettiği yeri almış olan Francis Bacon ve onun dışavurumcu yoğun duygu yüklü sanatına yeniden dikkat çekmektir.

Anahtar Kelimeler: Francis Bacon, Figüratif Resim, Resimde Dışavurum, Devinim ve Sanat.

The Attraction of Emotion and Tension in Painting Francis Bacon (1909-1992)

\begin{abstract}
Francis Bacon was born in Dublin in 1909 to an English family. The artist rejected the literary field and perceived his painting directly as an act of expressionism. The period he lived in and the effect he had on it was reflected in his paintings as horrifying images emerged in them. The figures in his paintings were distorted, trapped in a strong motion, caught in a vortex or storm. The audience subjected to the emotional tension of the figures were subjected to intense emotions.

The aim of this study, which was conducted by qualitative research method, is on Francis Bacon who, even though did not receive academic art education, managed to have a strong emotional effect on the audience with his expressionist art.
\end{abstract}

Keywords: Francis Bacon, Figurative Painting, Expression in Painting, Motion and Art. 


\section{Giriş}

İlk kez Londra'da 1930'ların sonlarında resim yapmaya başlayan Fransiz Bacon'un olgunluk çağı üslubu II. Dünya Savaşı’nın sonlarına uzanır. O zamanın ruh haline çok uygun olan, ona özgü temalar şiddet, acı çekme ve birey olarak insanın yalnızlığıdır. Sanatçı edebi olanı reddeder ve resmini doğrudan expresyonist olarak değerlendirir (Herrison ve Wood, 2011,s.676).

Francis Bacon umutsuzluğu, acıyı ve insanın varoluşuna olan tutkusunu eserlerine yansıtan ve bu duyguyu aynı yoğunlukta izleyiciye geçiren önemli bir isimdir. Sanatın bu denli duygu yüklü gücünün önemli bir göstergesini temsil etmeyi başaran Bacon, eserleri ile sanat tarihinde hak ettiği önemli yeri almıştır.

Araştırmada; eserleriyle günümüzde ve gelecekte ilham vermeye, ilgi çekmeye devam edecek olan sanatçının kısaca yaşam öyküsüne değinildikten sonra, duygu yoğunluğu ve dişavurumcu özgün figüratif anlatımıyla yenilikçi ve yaratıcı sanat anlayışına dikkat çekilmiş, eser örnekleri üzerinden genel değerlendirme yapılmıştır.

Nitel araştırma yöntemiyle gerçekleştirilen bu araştırmada verilerin toplanması "genel tarama" modeli çerçevesinde; konuyla ilgili kitaplar, dergiler ve internet kaynaklarından yararlanılarak gerçekleştirilmiştir. Literatür taramasından ve sanatçının eser görsellerinden elde edilen veriler “betimsel analiz” yöntemiyle çözümlenmiş ve sonuca gidilmiştir.

\section{Francis Bacon (1909-1992)}

'Francis Bacon, 1909'da İrlanda'da aristokrat bir İngiliz ailesinde dünyaya gelir. Babası 1914'te Londra'da Savaş Ofisi'nde çalışmaya gittiği için ailesiyle Londra ve İrlanda arasında gidip gelerek bir yaşantı sürer. Ayrıca Bacon zaman zaman, County Kildare'in Emniyet Müdürü’yle evli büyükannesiyle de yaşamıştır. İngiliz yönetimine karşı, sivil savaşın şiddetlendiği dönemlerde, Francis Bacon büyükannesinin kum torbalarıyla siperlenmiş evini, yollardaki keskin nişanc1 tuzaklarını, İngilizlerin askeri manevralarının ve çocukluğuna sinen genel bir tehlike duygusunu her zaman hatırlar" (Fineberg, 2014, s.137). 
Bacon köpeklere ve atlara alerjisi olan ağır astım hastası bir çocuktur. Aynı zamanda efeminedir ve kadınsı giyinmekten hoşlandığından sık sık dayak yemektedir. 1914'te I. Dünya Savaşı başlayınca ailesi Londra'ya taşınır ve Bacon iki yıllığına bir okula gönderilir ve resmi eğitim tecrübesi yalnızca bu okul olur (Thompson, 2014, s.314).

Ailesi Bacon'ın cinsel eğilimini kabullenmez ve 1927'de 17 yaşındayken evden ayrılır. Eşcinsel, gece hayatı ve aynı zamanda entelektüel çevrelerin de yer aldığı Almanya’nın başkenti Berlin’e ve sanat galerilerini dolaşmak sanatla daha fazla ilgilenmek için Paris'e seyahat eder, bir süre dolaşır. Bacon 1920'lerin sonunda Londra'ya döndüğünde, iç dekorasyonda kısa bir kariyere başlar ve aynı zamanda Art Deco'dan etkilenmiş, modern tarzda mobilya ve kilim tasarlar. Bacon ilk başta Picasso'dan etkilenerek Kübist ve daha sonra Sürrealist tarzda resim yapmaya başlar. Sanatçının kendi kendini yetiştiren çalışması ilgi görmeye başlar ve 1937'de "Genç İngiliz Ressamlar" başlıklı bir Londra karma sergisine katılır (Biography.com Websitesi, Francis Bacon). Sanatçı, Picasso ve sürrealizmden etkilenerek yaptığı yağlı boya resimlerinin çoğunu daha sonra imha eder (Farthing, 2012, s.465). Resim eğitimi almadan kendini yetiştiren sanatçı resimlerinde gerçeküstü, sürrealist tarafının yanında güçlü bir dışavurumcu, duygu yüklü anlatıma sahiptir.

1992 yılında Madrid' te hayata veda eden sanatçı, eserleriyle hak ettiği üne sahip olmuş ve dünyanın tanıdığı, İngiltere'nin 20. yüzyılın en büyük, en iddialı figüratif ressamı olmayı başarmıştır.

\section{Duygu ve Gerilimin Resimde Karşılığı Francis Bacon'ın Sanatı}

1930'larda başladığı resim çalışmaları İkinci Dünya Savaşı sonrasında önemli bir aşamaya gelmiş sanat kariyeri başlamıştır. Çağın insanının içinde bulunduğu korkutucu ve kötü durumu Bacon çarpıcı bir şekilde, yüksek hayal gücüyle görünür kılar. Sanatçının resimlerinde bilinçli seçilen nesneler ve bu nesnelerin içinde yer aldığı gizemli mekan, mekanın donuk görünüşü, renk eserlerinin duygu yoğunluğunu ortaya çıkartır. Vermek istediği gerilimli duyguyu izleyiciye çok çeşitli çağrışımlarla yaşatması Bacon'un sanatının gücünü gösterir. "Bacon'ın yapıtlarının, Batılı adamın acılı yalnızlığının ifadesi olduğu söylenir. Resimlerindeki figürler, cam sandıklarda, saf 
renkten oluşan geniş alanlarda, kimliksiz odalarda, hatta kendi içlerinde yalıtılmıştır. Yalıtılmış olmaları seyrediliyor olmalarını engellemez... Bacon'ın figürleri yalnızdır, gene de mahremiyetten bütünüyle yoksundur” (Berger, 2018, s.347). İzleyici Bacon'ın eserleriyle merhametsiz Dünya'nın olduğu gibi yansıtılmasına ve etkileyici, çarpıcı anlatımına tanık olur diyebiliriz.

"Bacon için resim, sinir sisteminin iki boyutlu yüzeye aktarıldığı, soyutla figüratif arasındaki ince dengede belirmektedir. Sanatçı belirli bir imge, fotoğraf ya da modelden yola çıkarak bunları tümüyle çarpıtıp, ortaya daha şiddetli ve gerçek olanı çıkartmıştır. Çok soğuk, yalın ve o denli şiddet dolu iç mekanlardaki insanlar sanki intihar, ölüm ve işkence anında belgelenmiştir" (Eczacıbaşı Sanat Ansiklopedisi, 1997, s. 179).

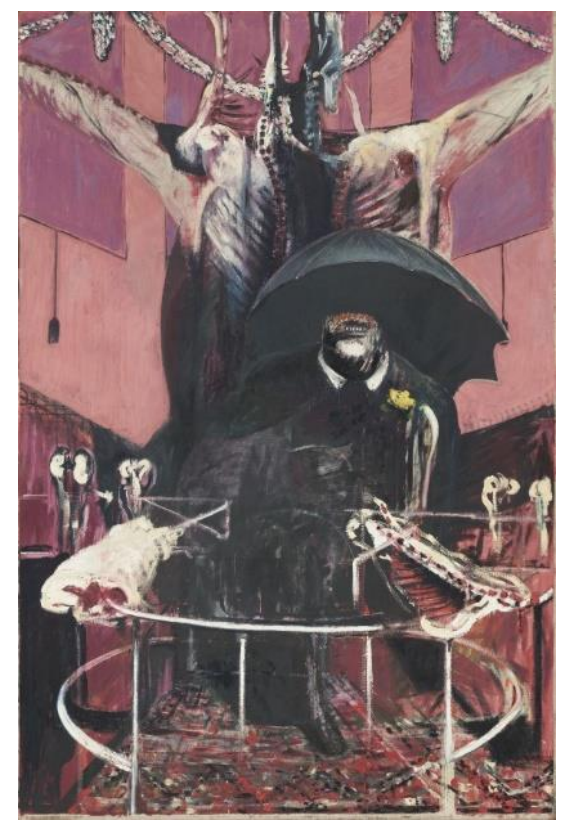

Resim 1.Francis Bacon, 1946, Tuval Üzerine Yağlı Boya, Pastel Tekniği, (197.8x132.1cm.).

II. Düya Savaşının hemen sonrasında yapılmış bu resimde (Resim 1) geometrik bir çember şeklinde çizilmiş bir mekan içinde anonim bir halk figürü ve onu kısmen gizleyen bir şemsiye dikkat çeker. Resmim merkezinde duran figürü incelediğimizde; günün İngiliz siyasetçilerinin resmi olmayan üniforması olan koyu renk elbisesi ve onun yakasına iliştirilmiş parlak sarı renk çiçek görülür. Ayrıca bu halk figürünün ölümcül ten rengi ve dişlek yüz buruşturması, dış cephesinin altında derin bir vahşilik olduğunu da göstermektedir. Arka planda üç pencere gölgesi Hitler sığınağı fotoğrafından alınmış çağrışımı yapar. Tehlike hissi, göz kamaştırıcı renkler ve 
arkasındaki haç biçiminde asılı inek karkasları ile vurgulanır. Bu Bacon'un çocukluğundan beri büyülendiği kasap dükkanlarına ilgisini gösterirken diğer yandan eski ustalara da gönderme yapıyor olabilir (Moma.org Websitesi, Sanat ve Sanatçılar: Francis Bacon).

Bacon'ın resimlerinin odak noktasını insan figürü oluşturur. Olay figür etrafında döner ve resmin diğer objeleri yardımcı imgelerdir. Sanatçıya göre "Kilit çözücü" nesne, her zaman insan bedenidir. Resimlerindeki diğer şeyler (iskemleler, pabuçlar, panjurlar, elektrik düğmeleri, gazeteler) sadece resmedilmiştir” (Berger, 2018, s.347). Kendi özgün üslubu ile yeni bir biçime kavuşan figürler sanatçının hislerinin dişavurumunu güçlendirir.

Yaşadığı dönem ve onun üzerinde bıraktığı etki resimlerinde korku, acı, çığlık ve karamsar bir bileşkenin sonucunda ortaya çıkan duygu patlamasıyla bir haykırış gibidir. Sanatçı; dışavurumcu sanatı ile kendini, duygu ve hislerini açık ve belirgin bir şekilde ortaya koyabilen başarılı bir anlatım örneği vermektedir. İzleyen sanatçının eserlerinde betimlediği duygunun bu kadar doğal ve bir o kadarda etkileyici geçişi içinde zamansız kaybolabilir.

Sanatçının korku veren imgelerden oluşan yapıtları oldukça büyük boyutlarda yapılmıştır. Bacon'ın resimlerinde bir sahneye benzeyen, insana yakın ve sıcak bir yeri hatılatan; aynı zamanda kapalı yerlerde kalma korkusu uyandıran boşluklar dikkati çeker. Bu boşluklardan yararlanan sanatçı, izleyenlerde dehşet ve korku duygularını harekete geçirir. Bunlar, devlet yönetimine muhalif olanların yok edilmesine yönelik korkular olabileceği gibi, günlük yaşamın bir parçası haline gelmiş gaddarlıklar karşısında hissedilen korku ve dehşette olabilir (Lynton, 2009, s.258).

Pek çok resminde insan figürü kafeslenmiş gibi bir geometrik çizimle çevrelenir. Figürün çevresini saran çizgisel prizma sanatçının iç mimarlık deneyiminin etkisi olarak görülebileceği gibi, resimde oluşturulan kompozisyonda dikkatleri belirli alana yönlendirme, mekan fikrine gönderme ve betimlenen figürün duygusal gerilimine ortak olma gibi izleyeni kendi içine çekerek yoğun duygu yaşamasını sağlayabilme gücüne erişmiştir. Bir mekanın içine sıkışmış acı veren, kurtulmayı isteyen, haykıran bir çı̆̆lık olan insanın iç tepisine, gerilimli duygularına anlam katmaktadır. Aslında büyük bir başarıyla yansıttığı, dışa vurduğu bu gerilimli duyguları sanatıyla bir zafere çevirmiş ve güç kazanarak olumsuzluktan zaferle çıkılmayı başarmıştır denilebilir. Tıpkı yaşamın içinde var olan olumsuzluklar için verilen mücadelenin insanı güçlendirdiği gibi Bacon'ın sanatını ve anlatımını da güçlendirmiştir. Korku ve acının getirdiği zafer ve umut olmuştur. 
Bacon eserlerini, insana acı veren bu olayların çoğunun açığa vurulmasında gerçekte belli bir emek harcamadan acı çekmeyen halktan insanların fotoğraflarından yararlanarak yapmıştır. Aralarında Çömelen Çıplak Üzerine Incelemeler'in de bulunduğu pek çok tablosunda sanatç1, Muybridge'in insan ve hayvan hareketleri üzerine yaptığı bilimsel incelemeleri kapsayan bir dizi fotoğraftan yararlanmıştır. Francis Bacon'ın ürküntü veren figürlerinin böylesine güzel boya pasajlarıyla sunulması, çok daha sarsıcıdır. Halbuki kullandığı araçlar ve verdiği ileti arasında böylesine etkili bir uyuşmazlık yaratmayı, yalnız Goya başarmıştı. Bir bakıma bu ikileme dayanılarak, Bacon Sürrealist gelenekten çok Ekspresyonist geleneğe yakın bulunabilir. Öteki nedenler göz önüne alınınca da ona Moore'un yanında yer verilebilir (Lynton, 2009, s.258).

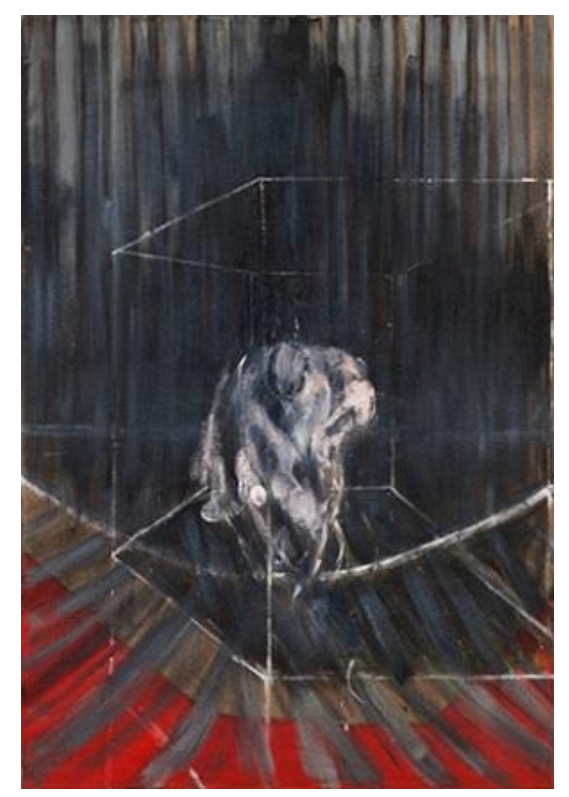

Resim 2. Bacom, 1951, “Çömelen Çıplak”, Tuval Üzerine Yağlı Boya, (196.2 x 135.2 cm.).

Resimlerde figürler hafif karanlık koyu renkli mekanda, güçlü bir devinim içinde çarpıtılmış, eğilmiş, bükülmüş ve güçlü bir duyguya kapılmış bir hal alır. 
Genellikle Bacon'un eserlerinde çığlık varılabilecek en güzel yorum olacaktır. Kimi zaman figürün sahici çığlığı, kimi zaman eserin bütününde algının sonucunda ortaya çıkan çığlık. Ki bu çığlık öğle güçlü, öyle gerçek, öyle etkileyici ki izleyen her bireyle bütünleşir ve çoğalır etkiye sahiptir.
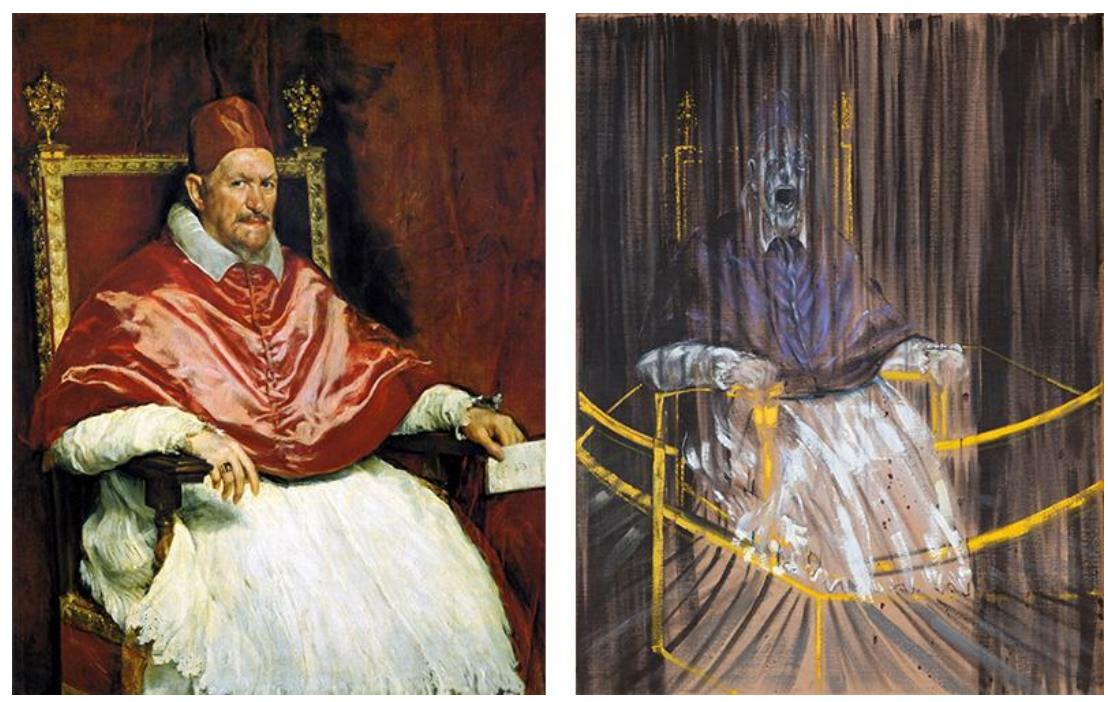

Resim 3. Diego Velázquez, Portrait of Pope Innocent X , 1650 - Francis Bacon'ın Eseri 1953 Velázquez'in Masum Papa X Portresi'nden sonra çalışan Francis Bacon, Tuval Üzerine Yağliboya, $(153 \mathrm{~cm} \times 118 \mathrm{~cm})$.

Sanatçı 1950'li yıllarda bir dizi çığlık atan papa resmi yapar. Burada Bacon'a ilham veren yapıt Diego Velazquez'in Portrait of Pope Innocent X (Masum Papa X) tablosudur (Resim 3). 16-17 yüzyıl dönemine ait önemli ve ağırbaşlı eserlerden yola çıkarak yaptığı resimlerine sanatçı; rahatsız edici, şaşırtıcı, çılgınca duygular katar ve zıt karakterler ortaya koyar.

Bir başka yoruma göre; Francis Bacon tarafindan Velazquez'in 17. Yüzyılda çizdiği ünlü Papa X. Innocentius Tablosu; tersyüz edilmiş bir dindarlıktır. Bacon'un değişiyle hırslı bir ateistin "coşkun umutsuzluğu”'. Bacon'un atölyesinde, Kilise'nin Babası korkunç bir titrek ışığa indirgenmiş, içten dışa ve dıştan içe doğru iki boşluğun arasında sıkışıp kalmıştır. Yaşlı Usta'nın resminin fotografik reprodüksiyonundan çalışan Francis Bacon, görüntüyü gergin bir ruh haliyle ortaya koymuş ve bunu Rus yönetmen Sergei Eisenstein'den aldığı bir film karesindeki çı̆̆lıkla birbirine bağlamıştır. Bacon'ın bakış açısından resim sanatı için geriye kalan, iç organlarda bir an için şok yaratma iddiasıdır (Bell, 2009, s.416). 
Yaklaşık 1650 yılında Velázquez'in yaptığı resmin orijinalinde papanın ağzı sıkıca kapatılmıştır. Ancak Bacon'ın 1950'lerin başından itibaren yaptı̆̆ı bu tür resimlerinin çoğunda figür çı̆̆glık atıyor ve kafese kapatılıyor. Bacon, röportajlarda "ağız ve dişlerin gerçek görünümüne her zaman çok takıntılı olduğunu" ve "her zaman Monet'in bir gün batımını resmettiği gibi ağzı boyamayı umduğunu" söylemiştir (CNN Style Websitesi, 2019).
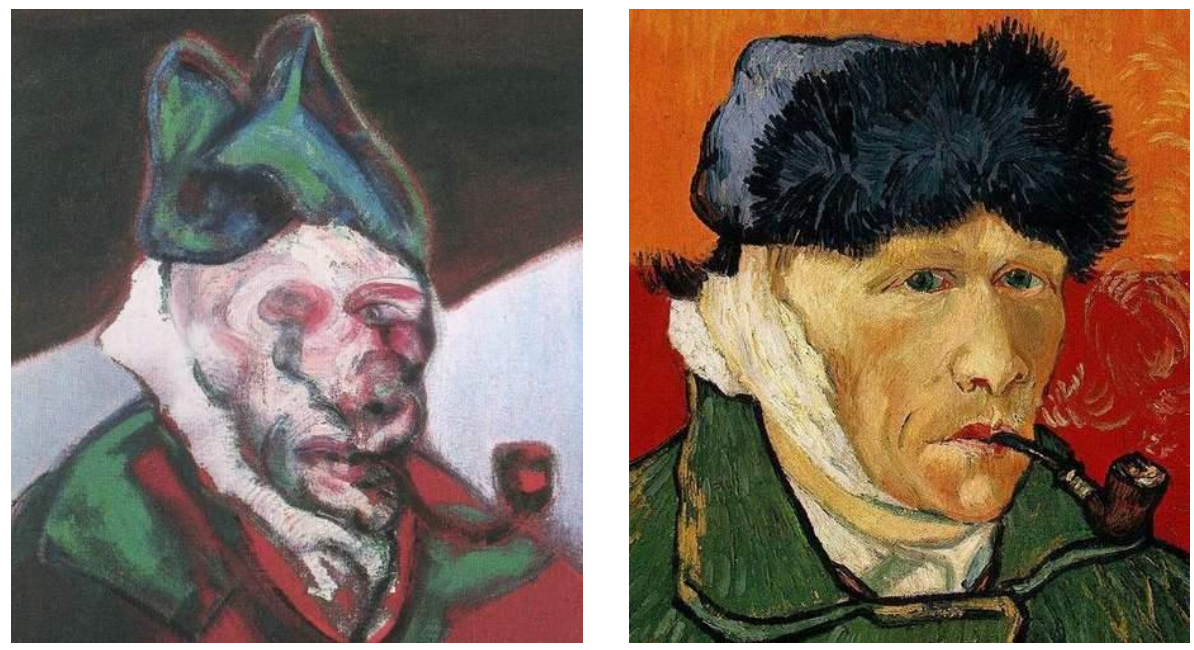

Resim 4. Francis Bacon, 1960, Tuval Üzerine Yağlı Boya, (86 x 86 cm.).

Sanatçı, farklı dönem sanatçıların eserlerinden yola çıkarak özgün yorumunu ortaya koymaya devam etmiştir. Yukarıdaki eser (Resim 4) 1960 yllında Bacon'ın Van Gogh'un kendi portresinden yaptığı eseri ilham alarak gerçekleştirdiği çalışmasıdır.

Resmin ana temasını oluşturan insan figürü ve portredeki ifade sanatçının düşüncelerini tam olarak dışa yansımasını gerçekleştirir biçimde kompoze edilmiştir. Bacon'ın resimlerinde kullandığı renkler ve biçimler konuyu destekler niteliktedir.

Sanatçının "ilgisi parlak cadde ve bulvarlardan fersah fersah uzaktaki arka sokaklara dönüktü. Oysa o dönemki gerçekçi sanatın büyük çoğunluğu heyecansız yapıtlar üretiyor, temsil edilenden çok temsilin kendisiyle ilgileniyordu" (Godfrey, 2016, s. 14).

Francis Bacon'ın ilgisini çeken basit halk tabakasıdır ve onların çektikleri acılardır. Yaşamın merkezinde etkilendiği, hissettiği her şeyi duyumsayarak eserleriyle dışa vurmakta, özgün bir dille 
ortaya koymaktadır. Onun için insan ve duyguları önemlidir ve eserlerinde figür ön plandadır ve kompozisyonun önemli bir parçasıdır.

Sanatçı resimlerini yaparken tesadüflerin oynadığı rolün önemine değinir ve anlattığı durumların pesimistliğini inkar etmez, fakat bunlardan "oyun... neşeli birer umutsuzluk", olarak bahseder. 23 Mart 1963'te yayınlanmış Bacon'un David Sylvester'le yapmış olduğu söyleşide resimlerinde tesadüflerin önemini şu örneği vererek anlatır: "1946 yılında yaptığım resimlerden biri, kasap dükkanı gibi olan resim, tesadüfen ortaya çıktı. Bir tarlaya konan bir kuş yapmaya çalışıyordum. $\mathrm{Bu}$ da bir şekilde daha önce çıkmış olan üç biçimle iç içe geçmiş olmalı, ama ansızın çizdiğim çizgiler tümüyle farklı bir şeyi düşündürdü ve bu düşünceden de bu resim ortaya çıktı. Bu resmi yapmaya niyetim yoktu hiç; hiç bu şekilde olacağını düşünmemiştim. Sanki peşpeşe kazalar üstüste bindi” (Herrison ve Wood, 2011, s.676).

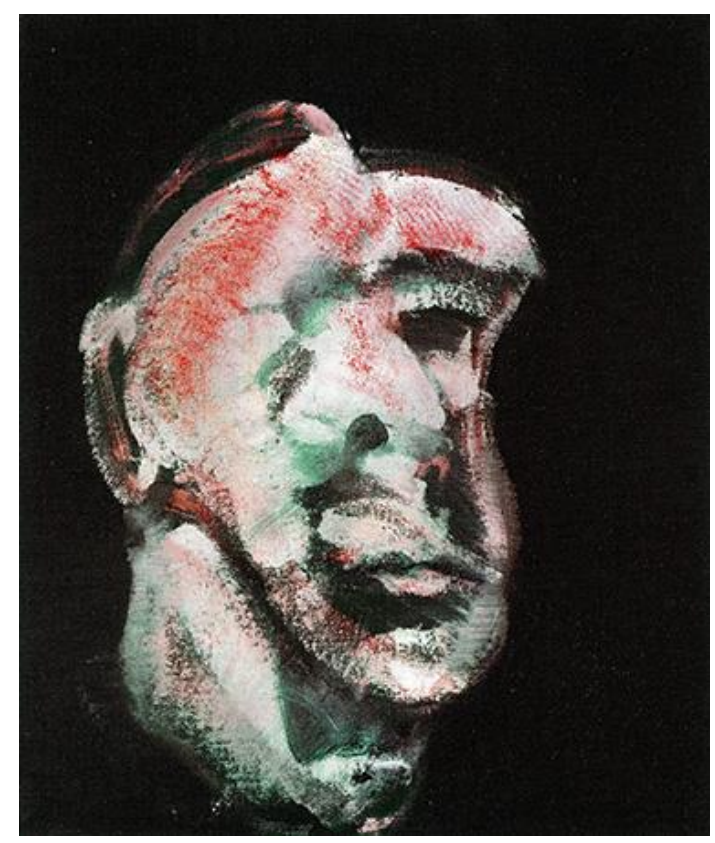

Resim 5. Bacon, 1961, Head I (Kafa I), Tuval Üzerine Yağlı Boya, (37.5 x 31 cm.).

Yine aynı söyleşide; "Biçimin nasıl yapılabileceğini bilmiyorum. Sözgelimi, geçen gün birinin başının resmini yaptım (Resim 5, Head I) ve göz çukurlarını, burnu, ağzı yapan şey, onları çözümlediğiniz zaman, gözlerle, burunla ya da ağızla hiç ilişkisi olmayan biçimlerden ibaret; ama bir konturdan diğerine geçen boya, resmini yapmaya çalıştığım kişiye bir benzerlik sağladı. Durdum; bir an için istediğim şeye çok daha yakın bir şey elde ettiğimi düşündüm. Sonra ertesi 
gün onu biraz daha ileri götürmeye çalışıp daha keskin, daha yakın bir şey yapmaya çalıştım ve imgeyi tümüyle kaybettim. Çünkü bu imge figüratif resim denen şeyle soyutlama arasındaki bir tür ip yürüyüşü gibi. Dosdoğru soyutlamadan çıkacak ama aslında onunla hiçbir alakası olmayacak. Figüratif şeyi daha şiddetli ve keskin bir şekilde sinir sistemine sokma çabası bu"'(Herrison ve Wood, 2011,s.677). Yapmaya başladığı bir resimde süreç içinde imgenin kazayla farklı bir ifadeye dönüştüğüne, tesadüflerin sanata ve sanatçıya önemli katkısına dikkat çekilmektedir. Tüm bunlar; sanatçının ifade biçimi ve güçlü duyguların özgün yorumu olarak değerlendirilebilir.
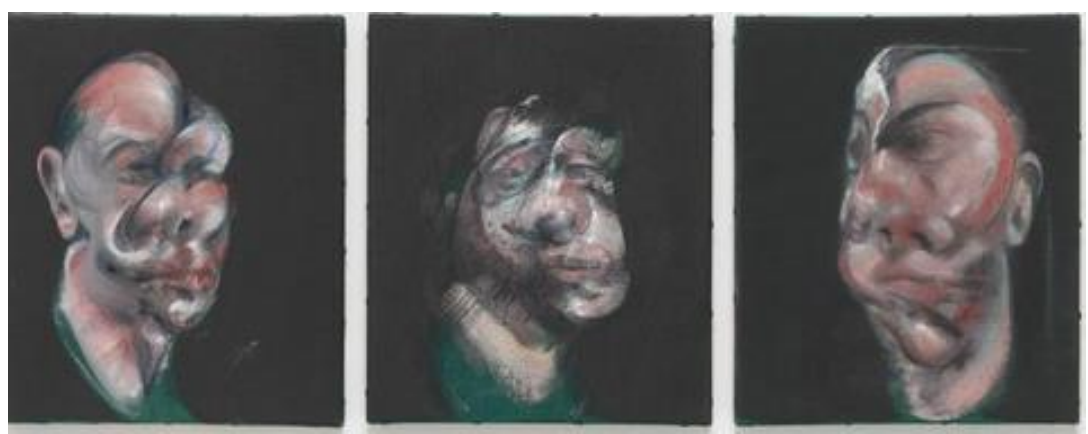

Resim 6. Bacon, 1962, "Üç Kafa” Çalışması, Tuval Üzerine Yağlı Boya, Her Panel: (35,9 x $30,8 \mathrm{~cm}$.).

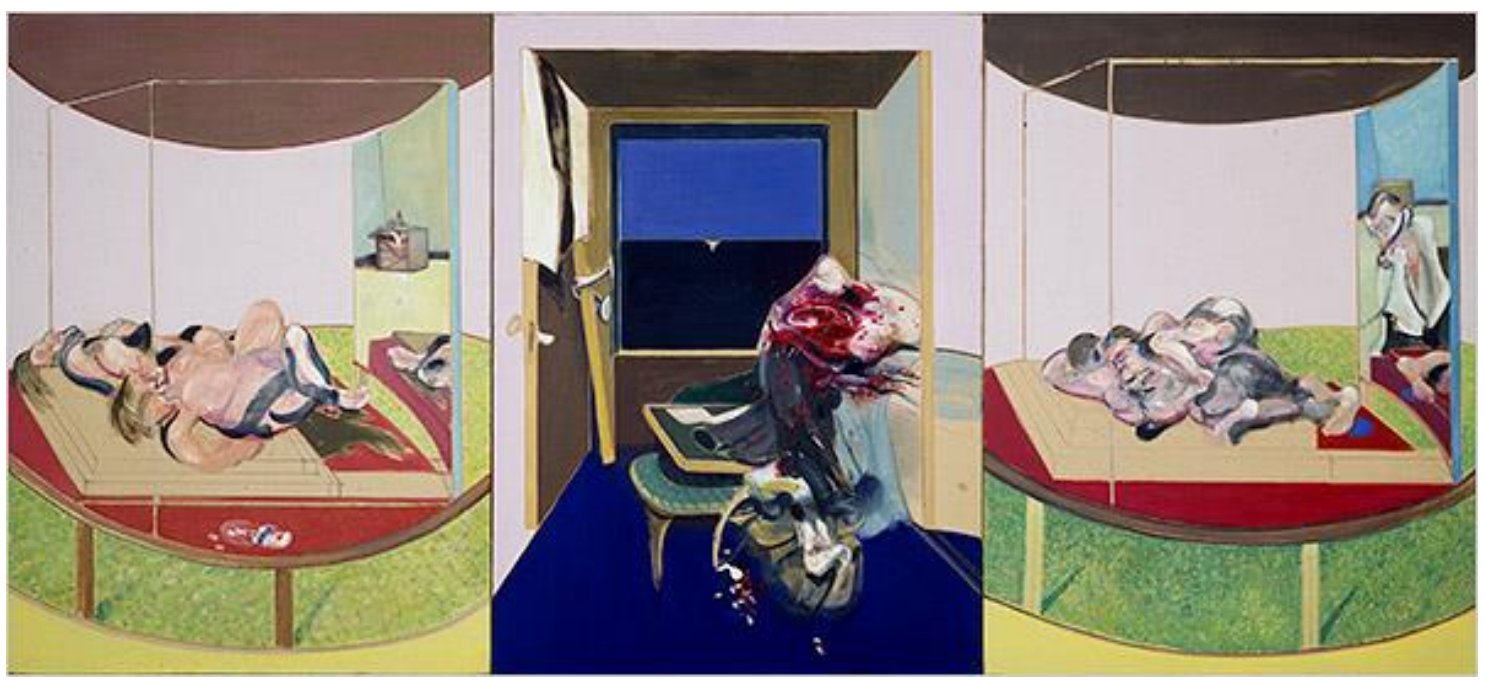

Resim 7. Bacon, 1967, Tuval Üzerine Yağlı Boya, Üç Panel Halinde: (a) 198,8 x148.3 cm. (b) $198,8 \times 148 \mathrm{~cm}$, (c) $200,3 \times 148 \mathrm{~cm}$. 
Bacon bu triptik resmi (Resim 7), İngiliz şair T. S. Eliot'1n "Sweeney Agonistes" eserinden ilham alarak yapar. Soldaki panelde, erkek sevgililer, üçüncü kişinin resmin sağ tarafindan henüz çıktığının farkında değilmiş gibi görünürler. Sağ panelde zamanın tersine döndürüldüğü ve aynı üçüncü kişi bir yandan telefonla konuştuğu birine tıpkı yazar Eliot'un dizelerinde ima ettiği gibi “doğumdan, cinsel ilişkiden ve ölümden bahsederken” aynı zamanda yaşanmakta olan ilişkiye bakmaktadır. Ortadaki panelde kanlar içinde Sweeney figürü, kapalı bir alanda üzerindeki elbiseleri çıkartırken yalpalayarak yürümektedir. Eliot'ın John Milton'ın "Samson Agonistes”inie gönderme yaparak yazdığı gibi “... onun kadar yalnız olduğunda ister istemez, öyle veya böyle, ya ölüsündür ya da diri” (Thompson, 2014, s.314-315). Sanatçının resimlerinde s1k s1k karşılaştı̆̆ımız gibi figürler geometrik dairesel çizimle oluşturulan mekanlar içinde yer almaktadır ve figürler arasındaki bağlantılı hikaye öne çıkmaktadır.

Bacon'un David Sylvester'le yapmış olduğu söyleşide resimlerindeki bir veya birden fazla olan figürlerle ilgili açıklaması şöyledir: "Resmin içinde bulunduğu karmaşık durumda, birkaç figür olduğu anda - her koşulda aynı tuval üzerine birkaç figür - hikaye gelişmeye başlar. Ve hikaye geliştiği anda, sıkıntı yerleşir; hikaye resimden daha yüksek sesle konuşur. Bunun nedeni aslında bir kez daha çok ilkel zamanlara dönmüş olmamız ve bir imgeyle diğeri arasında hikaye anlatmayı iptal edememiş olmamızdır" (Herrison ve Wood, 2011,s.678).

1960'lar ve 1970'ler Farancis Bacon'un sanatında büyük başarıların kazandığı zaman dilimi olmuştur ( Felber,1981, s.2).

Bacon 1971 senesinde sevgilisi, arkadaşı ve modeli olan George Dyer'in ölümünden fazlasıyla etkilenir ve duyduğu derin üzüntü onun resimlerine doğrudan yansır. Sanatçının "Black Triptyc" isimli eseri (Resim 8), George Dyer'in intiharından hemen önce ve sonra geçen anların sahnelerini içerir. Resimler Bacon'un hayatındaki bu trajik olayın "acımasız tasviri” olarak tanımlanırken aynı zamanda sanatçının en büyük başyapıtlarından biri olduğu da kabul edilmiştir (Kunzt.gallery Websitesi, Francis Bacon). 


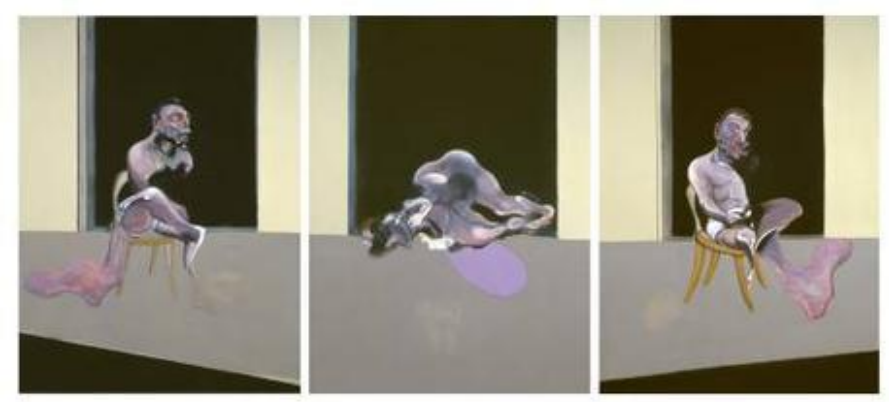

Resim 8. Bacon, 1972, “The Black Triptychs” Tuval Üzerine Yağlıboya, Tata Galeri Bacon'un "Çarmıha Gerilme” Serisinden Örnekler

Bacon farklı yıllarda çeşitli "Çarmıha Gerilme”" temalı resimler yapmıştır ve bunların ilki 1933 tarihlidir (Resim 9).

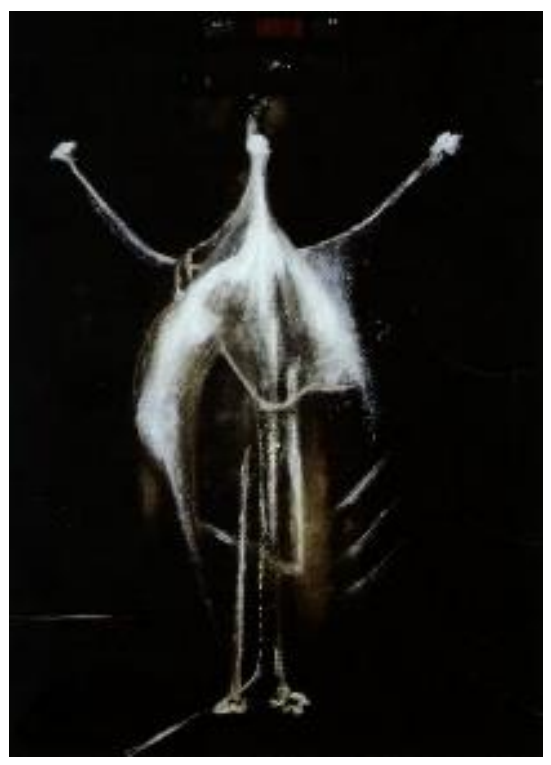

Resim 9. Bacon, 1933, “Çarmıha Gerilme”, Tuval Üzerine Yağlı Boya, (60.5 x 47 cm.) .
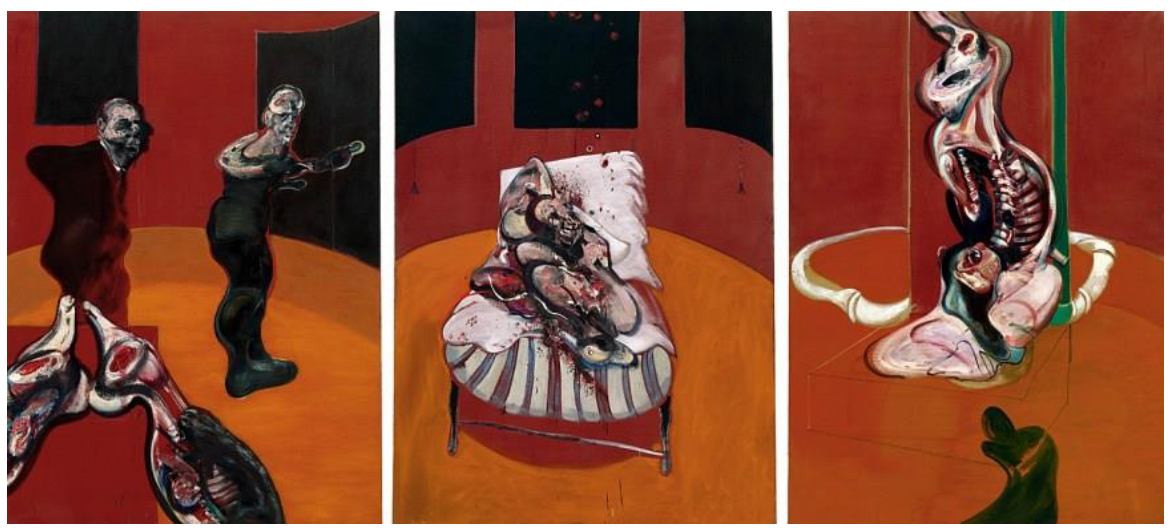

Resim 10. Bacon, 1962, “Çarmıha Gerilme Üç Etüd”, (198.1 x 144.8 cm.). 
Sanatçı 1962 ve 1965 tarihlerinde yaptığı "Çarmıha Gerilme" resimlerini triptik şeklinde tasarlamıştır.

Francis Bacon “Çarmıha Gerilme Üç Etüd 1962”(Resim 10) eserini Londra'daki Tate Gallery'de açılacak retrospektif sergisi için yapar ve resmi Birleşik Devletler'in önde gelen modern sanat müzelerinden biri tarafından satın alınmasıyla sanatçı figüratif ressam olarak uluslararası bir üne sahip olur. Bacon'ın vahşet, cinsellik ve ölüm temalarını işleyiş tarzı, yaşadığı dönemde son derece aşırı bulunmuştur (Farthing, 2012, s.464).

Eski ustaların pek çoğunun yaptığı dini temalar onda güncel insanın içinde bulunduğu bir durumun göstergesi gibidir ve sanatçının dışavurumcu üslubunun bir yorumudur.

“İsa’nın çarmıha gerilmesi Avrupa sanatında yüzyıllardır kullanılan bir temaydı ve Bacon bu temayı dünyevi bağlama oturtarak kurban etme ritüelleri ile ilgili çağrışımları kendini ifade etmeye yarayan bir araç gibi kullandı. Sanatçı, çarmıha gerilmeyi insan davranışlarında var olan vahşet ve şiddetin sembolü olarak görüyordu. Bu düşüncesini, kurbanı kasaplık et gibi tasvir ederek vurguluyordu" (Farthing, 2012, s.464).
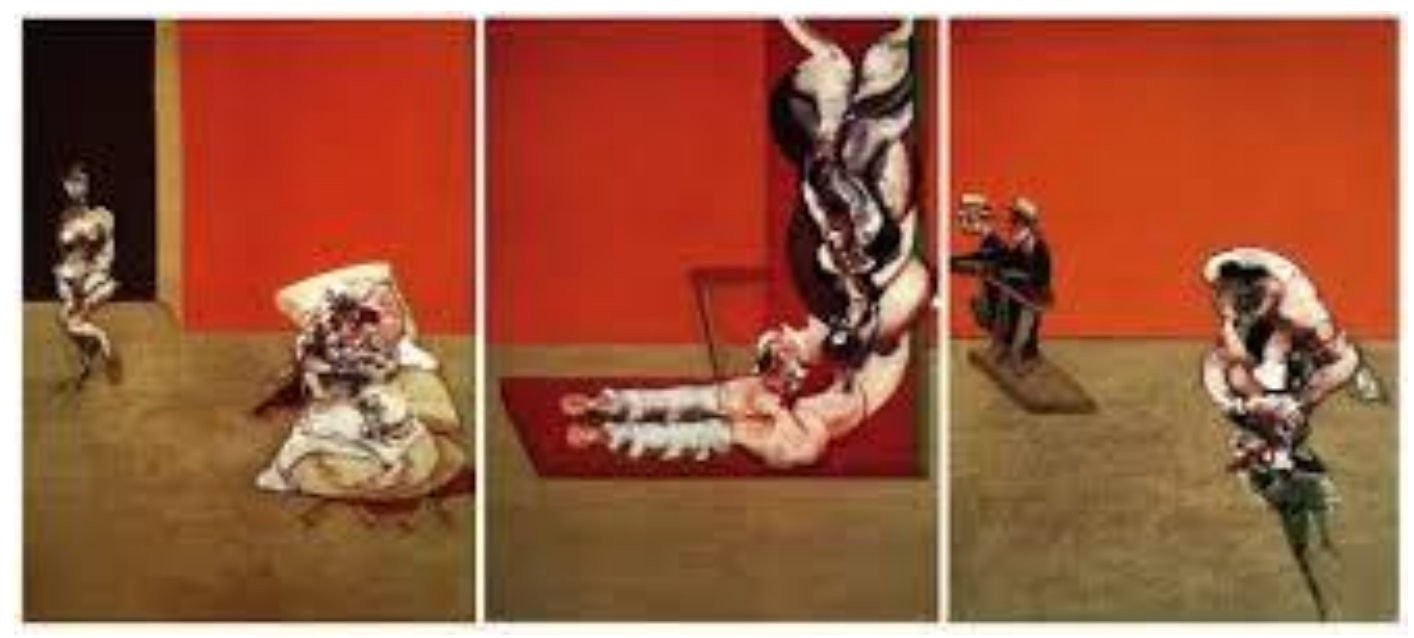

Resim 11. Bacon, 1965, “Çarmıha Gerilme”, Munich, (197.5cm x 147cm.).

1962 de yaptığı “Çarmıha Gerilme Üç Etüt” ile 1965'te yaptığı "Çarmıha Gerilme” eseri renkler ve formlar benzerlik göstermektedir. 1965 'te yaptığı resimde et karkası orta bölümde figürlerle 
birlikte mekan içinde yerini alır. Diğerlerinde olduğu gibi resmin bütünü dehşet, ac1, ölüm, çaresizlik gibi çok çeşitli zor duyguları barındırır ve sanatçı da bunu bilinçli ve başarıyla izleyene geçirir. Bacon bu konuyla ilgili olarak şöyle söyler: "Beni Mezbaha ve et konulu resimler hep etkilemiştir ve bana göre bütün bu Çarmıh meselesine çok yakın duruyor. Kesilmeden biraz önce çekilmiş sıra dışı hayvan fotoğrafları var; üstelik bir de ölümün korkusu. Elbette, bilmiyoruz, ama bu fotoğraflardan onların başlarına gelenlerin farkında olduğu anlaşıllyor, kaçmak için binbir çaba harcıyorlar. Bence bu resimler tam bu türden bir şeye dayanıyor, bana göre, Çarmıh olayına çok yakın olan bir şeye. Dinine bağlı insanların, Hıristiyanların, Çarmıhı tümüyle farklı bir önemde ele aldıklarını biliyorum. Ama inançsız biri olarak bana göre, bu insanın davranışlarının bir sonucu, bir başkasına davranma tarzıydı" (Herrison ve Wood, 2011,s.678). Yukarıda da belirtildiği gibi sanatçının her zaman mezbahalardan, kasap dükkanlarından, et ile ilgili görüntülerden, etkilendiğini ve bunu çarmıha gerilme temasıyla özdeşleştirdiğini öğreniyoruz. Bu benzetmeyi sanatçı çarpıcı bir anlatımla dile getirmektedir.

Sanatçının hareketli, başarılı, çok yönlü yaşantısının tersine iç yansıması olarak gördüğü olağan üstü düş gücüyle ortaya çıkmış eserleri; korku, acı, endişe, kaygı, hayal kırıklığı ve aynı zamanda biraz umut olarak kendini gösterir. İnsanın yalnızlığını, ölümün kaçınılmazlığını figür ve portrelerine yansıtır. Hayvan iskeletleri, insan gövdeleri, çarmıha gerilmiş figürler, çarpıtılmış portreler, insan- hayvan benzeri yaratıklar tasarlar. Eski ustaların eserlerinde yola çıarak özgün yorumlara ulaşır.

\section{Sonuç}

Sanatçı akademik bir resim eğitimi almamıştır, ama estetik bütünlük içinde renklerin, biçimlerin ustalıkla kullanımı ile yakaladığı yorum, kendini ifade etme başarısı onu dünyanın en önemli figüratif, dışavurumcu ve özel sanatçılar arasında yer almasını sağlamıştır. Eserlerinde önemli bir yeri olan çığlık izleyene aynı duyguları yaşatmayı başarmıştır. Her bir eser, insanın içinde tutamadığı duyguların dışa yansıması ile anlam kazanır ve izleyenin duygularıyla birleşerek güçlü etkilere sahip derin hisler ve unutulmaz anlar yaşatır. Sanatçının yaşam içindeki duyarlılı̆̆ hassasiyeti, mücadelesi, eserleriyle görsellik kazanır. Hayatın içindeki dayanılmaz acılar eserleriyle adeta insanlığın gözleri önüne serilir. Öyle ki gerçek olduğu gibi ortadadır ve bundan 
kaçamazsınız. Bu çoğu zaman acı veren yoğun duygu ile örülü eserlerin içindeki kendine özgü mücadele, yine Bacon'un eserlerinde hissedilecek ve derin acıdan zaferle çıkma gücü de verilecektir. Sanatçının eseriyle sürdürdüğü mücadele ve kazandığı zafer, insanı umutlandırır ve rahatlatır.

Denilebilir ki Bocon'ın resimleriyle karşılaşan hiç kimse kendisiyle yüzleşmekten kaçamaz, öyle ki bu yüzleşme kendi benliğimiz yanında dünyayı, insanlığı ve yaratılan kaus, kargaşa ve acıyla da olacaktır. Bu açıdan sanatın gücü ve zaferi önemlidir ve bunları yaşatmayı başaran sanatçının kendisi de çok özeldir.

Francis Bacon insanlığın kalbine dokunan sanatıyla elde ettiği başarıyı fazlasıyla hak etmiş ve sanat tarihinde yerini almıştır. Özgün yorumuyla ortaya koyduğu eserleri günümüzde ve gelecekte çağlar boyunca insanlığı etkilemeye ve ilham vermeye devam edecektir.

\section{Kaynaklar}

BELL Julian, (2009), Sanatın Yeni Tarihi, Çev: U. Ceren ÜNLÜ, Nurçin İLERİ, Rana GÜRTUNA, İstanbul: Doğuş Grubu İletişim Yayıncılık.

BERGER John, (2018), Portreler (Sanatçılar Üzerine Yazılar), Çev: Beril Eyüboğlu, 1. Baskı, İstanbul: Metis Yayınları.

(Biography.com Websitesi, Francis Bacon). https://www.biography.com/artist/francis-bacon (Erişim Tarihi: 13. 05. 2019).

(CNN Style Websitesi), "Visceral and unsparing: Why Francis Bacon's portraits of screaming popes and lovers live on", Published 29th July 2019

(https://edition.cnn.com/style/article/francis-bacon/index.html Erişim Tarihi: 24. 11. 2021).

ECZACI BAŞI SANAT ANSİKLOPEDİSI,, (1997), “BACON Francis" Maddesi, 1. Cilt, İstanbul: YEM Yayın.

FARTHING Stephen (Editör), (2012). Sanatın Tüm Öyküsü, Çev: Gizem ALDOĞAN, Firdevs Candil ÇULCU, İstanbul: Hayalperest Yayınevi.

FELBER Sylvie, 1981, “Francis Bacon: A Biography”, fondationbeyeler.ch (https://www.fondationbeyeler.ch/fileadmin/user_upload/Ausstellungen/BaconGiacometti/Bio/EN_Francis_Bacon_Biografie.pdf Erişim Tarihi: 25. 11.2021).

FINEBERG Jonathan, (2014), 1940'tan Günümüze Sanat Varlık ve Stratejileri, İzmir: Karakalem Kitabevi Yayınları. 
GODFREY Tony, (2016), Resim Bugün, Çev: Hasan Bülent KAHRAMAN, Akbank Kültür ve Sanat Dizisi: 85, İstanbul: Lal Yayınları.

HERRISON Charles ve WOOD Paul, (2011), Sanat ve Kuram 1900-2000 Değişen Fikirler Antolojisi, Çev. Sabri GÜRSES, 1. Baskı, İstanbul: Küre Yayınları.

(Kunzt.gallery Websitesi, Francis Bacon). https://www.kunzt.gallery/artist/francis-bacon/ (Erişim tarihi: 13. 05.2019).

LYNTON Norbert, (2009), Modern Sanatın Öyküsü, Çev: Cevat ÇAPAN, Sadi ÖZİŞ, 4. Basım, İstanbul: Remzi Kitabevi.

(Moma.org Websitesi, Sanat ve Sanatçılar: Francis Bacon).

https://www.moma.org/collection/works/79204 (Erişim Tarihi: 13. 05. 2019).

THOMPSON Jon, (2014). Modern Resim Nasıl Okunur, Çev: Firdevs Candil ÇULCU, 1. Baskı, İstanbul: Hayal Perest Yayınları.

\section{Görsel Kaynaklar}

Resim 1: https://www.moma.org/collection/works/79204 (Erişim Tarihi: 13. 05. 2019).

Resim 2: https://www.francis-bacon.com/artworks/paintings/crouching-nude (Erişim Tarihi: 20. 05. 2019).

Resim3:https://en.wikipedia.org/wiki/Study_after_Vel\%C3\%A1zquez\%27s_Portrait_of_Pope_I nnocent_X (Erişim Tarihi: 13. 05. 2019).

Resim 4: http://www.alexalienart.com/portraitshtlm.htm (Erişim Tarihi: 17. 05. 2019).

Resim 5: https://www.francis-bacon.com/artworks/paintings/head-i-1(Erişim Tarihi: 13. 05. 2019).

\section{Resim 6:}

https://www.moma.org/collection/works/83361 ?artist_id=272\&locale=en\&page=1\&sov_referrer $=\operatorname{artist}($ Erişim Tarihi: 44.05.2019).

Resim 7: https://www.nytimes.com/2009/05/22/arts/design/22baco.html (Erişim Tarihi: 19. 05. 2019).

\section{Resim 8:}

https://en.wikipedia.org/wiki/The_Black_Triptychs\#/media/File:Triptych_-_August_1972.jpg (Erişim tarihi: 13. 05.2019).

Resim 9: THOMPSON Jon, (2014). Modern Resim Nasıl Okunur, Çev: Firdevs Candil ÇULCU, Birinci Baskı, İstanbul: Hayal Perest Yayınları. S.315.

Resim 10: https://www.guggenheim.org/artwork/293(Erişim tarihi: 13. 05.2019).

Resim 11: https://en.wikipedia.org/wiki/Crucifixion_(Francis_Bacon,_1965) (Erişim tarihi: 13. 05.2019). 